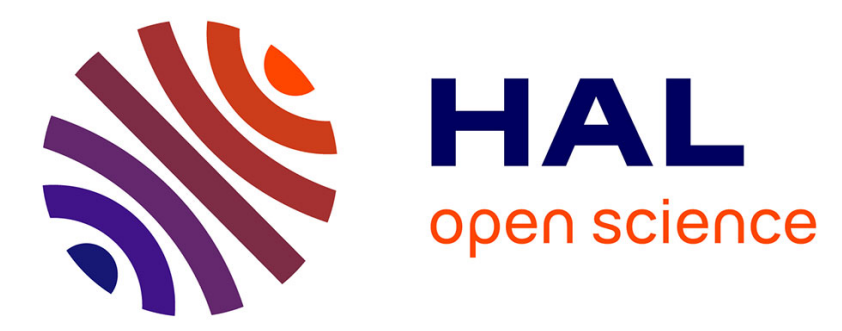

\title{
Household transitions and subsequent mortality among older people in England and Wales: Trends over three decades
}

\author{
Emily Grundy
}

\section{- To cite this version:}

Emily Grundy. Household transitions and subsequent mortality among older people in England and Wales: Trends over three decades. Journal of Epidemiology and Community Health, 2010, 65 (4), pp.353. 10.1136/jech.2009.089383 . hal-00573452

HAL Id: hal-00573452

https://hal.science/hal-00573452

Submitted on 4 Mar 2011

HAL is a multi-disciplinary open access archive for the deposit and dissemination of scientific research documents, whether they are published or not. The documents may come from teaching and research institutions in France or abroad, or from public or private research centers.
L'archive ouverte pluridisciplinaire HAL, est destinée au dépôt et à la diffusion de documents scientifiques de niveau recherche, publiés ou non, émanant des établissements d'enseignement et de recherche français ou étrangers, des laboratoires publics ou privés. 


\title{
Household transitions and subsequent mortality among older people in England and Wales: Trends over three decades
}

\author{
Emily Grundy \\ Centre for Population Studies \\ London School of Hygiene and Tropical Medicine \\ London, UK \\ Email: Emily.grundy@1shtm.ac.uk
}

Acknowledgements: Research reported here was supported by the UK Economic and Social Research Council (Award Ref. RES-339-25-0002). The permission of the Office for National Statistics to use the Longitudinal Study is gratefully acknowledged, as is the help provided by Christopher Marshall and other staff of the Centre for Longitudinal Study Information \& User Support (CeLSIUS). CeLSIUS is supported by the ESRC Census of Population Programme (Award Ref: RES-348-25-0004). Census output is Crown copyright and is reproduced with the permission of the Controller of HMSO. The author alone is responsible for the interpretation of the data.

Conflict of interests:None

The corresponding author has the right to grant on behalf of all authors and does grant on behalf of all authors an exclusive license on a worldwide basis to the BMJ Publishing Group Ltd and its licensees to permit this article (if accepted) to be published in JECH editions and any other BMJPGL products to exploit all subsidiary rights, as set out in our license (http:/jech.bmj.com.ifora.licence.pdf).

What this paper adds

What is already known

There have been major changes both in the living arrangements of older people and in long-term care policy and provision in England and Wales, and many other European countries. Changes in the availability of co-resident family care for older people has implications for demand for formally provided care, conversely long term care policies are an important potential influence on the residential choices of disabled older people. 
What this study adds

In England and Wales risks of moving to an institution in 1991-2001 were lower, and subsequent excess mortality of those making such a move, higher than in earlier decades. This suggests that policy reforms introduced in the 1990s led to a reduction in the use of institutional care and greater targeting of this resource on the most frail. Chances of living with relatives also show a downward trend suggesting other influences driving increased residential independence of older people. Differences in the mortality of older people living with relatives and those living in institutions indicates that the health status of these populations is not equivalent. 


\section{Abstract}

\section{Background}

The past thirty years have seen major changes in the living arrangements of older people and in long-term care policy in England and Wales. Co-resident family care and institutional care can be alternatives for seriously disabled older people, so changes in the availability of either may affect demands for the other.

\section{Aims}

To analyse changes in older people's living arrangements in three successive decades in England and Wales and compare the subsequent mortality of older people living with relatives; those living alone or with a spouse; and those living in institutions.

\section{Methods}

Cross sequential analysis of household circumstances at the beginning and end of three decades using multinomial logistic regression of data from the Office for National Statistics Longitudinal Study. Poisson regression analysis of subsequent mortality.

\section{Results}

Risks of moving to an institution 1991-2001 relative to living alone or in a couple were lower than in 1981-1991 for women and men and for women also lower in comparison to living with relatives. Chances of living with relatives rather than alone or in a couple showed a downward trend over time. Institutional residents had higher mortality than those living alone/in a couple or those with relatives. This excess was greater in 2001-05 than in previous periods, even so $26 \%$ of male and $36 \%$ of female institutional residents in 2001 survived three years.

\section{Conclusion}

Policy changes are important influences on use of institutional care. The health status of older people living with relatives and those in institutions is not equivalent. 


\section{Introduction}

Over the past three decades living alone or just with a spouse has become increasingly prevalent and living with relatives increasingly unusual for older people in most of Europe and North America. [1-3] Possible explanations encompass positive developments including higher incomes, better health, and improvements in housing, assistive technology, transport and communications. Such changes may have enabled more older people to meet preferences for residential independence and made it easier to provide extra-household help to those who cannot manage unaided. [4-6] Other interpretations have emphasised constraints, including possible declines in family support. [7,8] The proportion of older people with a spouse or child alive has increased in recent decades in England and Wales and other European countries because of historic changes in family formation patterns and mortality declines leading to later ages at widowhood. [9-11] However, the ability or willingness of younger generations to provide care, including co-resident care, for disabled older relatives (and older people's care preferences), may have fallen as a result of social changes including increases in the proportions of women working full time and greater individualism. [12-14] As family care is so important for older people with disabilities, any change in the availability of such support has implications for the demand for formally provided services, including institutional care. [15] Conversely, changes in the supply of formal care have implications for potential family supporters and long-term care policies are an important potential influence on residential choices and constraints among older people with disabilities. [16,17]

\section{Long-term care policy and provision in England and Wales ${ }^{1}$}

Long-term care provision for older people in England and Wales still bears the hallmark of the post World War II legislation which established the modern British welfare state. This included a requirement for local authorities to provide residential care and an empowerment to financially support residents in homes provided in the private (for profit) and voluntary (not-for-profit) sectors. Long-term hospital care became the responsibility of the National Health Service (NHS) and was free of charge, although local authority accommodation was from its inception means tested. Subsequent legislation incrementally extended and changed the relative responsibilities of the NHS and local authorities for providing other long-term care services, such as home help, meals, and day care. $[18,19]$

The past three decades have seen significant changes in both organisation and availability of long-term care services. After a period of expansion in the immediate post war decades, in the later 1970s and 1980s financial constraints meant that the provision of local authority paid-for residential and domiciliary long-term care services failed to

\footnotetext{
${ }^{1}$ There are a number of differences in long-term care policies in the constituent countries of the UK (England \& Wales, Scotland, Northern Ireland) which are not discussed here.
} 
keep pace with increases in the size of the older old population. [20, 21] Long- term hospital provision reduced substantially from the 1980s (in part associated with reductions in lengths of stay) with further large reductions more recently. [22, 23] Secondly, administrative changes in regulations on payment of supplements to those on low incomes introduced in 1980 made 'board and lodging' payments available to low income older people entering private and voluntary residential or nursing homes resulting in a huge expansion in provision and a ten-fold increase in (Central) Government expenditure on these supplements during the 1980s. [24] This increased provision was associated with changes in the balance between institutional care and co-residence with relatives. Research using data from the Office for National Statistics Longitudinal Study (ONS LS) showed that, after controlling for age, marital status and housing tenure, the risk of transition from a private household to an institution was some 33-52\% higher in 1981-91 than in 1971-81 while rates of transition to live with relatives declined. [25] Subsequently, attempts to rein back escalating costs and re-emphasise community care led to the introduction of the NHS and Community Care Act in 1990 (fully implemented in 1993). This returned to local authorities responsibility for arranging and funding (on a means tested basis) long-term care in residential and nursing homes. This legislation introduced a requirement for an assessment of older people moving into residential or nursing home care (apart from self-funders) and the targeting of home care resources on those most at risk of such a move. These policies appear to have had some effect in that admission rates levelled off during the 1990s [22, 23] and domiciliary services have become focussed on a smaller proportion of older people who receive larger amounts of support. [26] It is not known whether these changes have influenced rates of co-residence with relatives. There is also a lack of national information on whether the requirement for medical assessment prior to institutional admission led to a change in the health status of older people entering institutional care and their subsequent mortality.

\section{Aims}

The aims of this study were to identify possible effects of the NHS and Community Care Act and subsequent reforms firstly by analysing changes in the proportions of older people living with relatives and moving to institutional care in three successive decades in England and Wales, and secondly by comparing the subsequent mortality of older people living with relatives; those living 'independently'; and those living in institutions.

\section{Data and Methods}

I employ a cross sequential design to examine the household circumstances of older people at the beginning and end of three successive decades (1971-81, 1981-91 and 19912001) and contrast three end-of-decade living arrangements -residence in an institution; co-residence with relatives; and living alone or just with a spouse-, using multinomial logistic regression. Poisson regression was used to model differentials in mortality for each decade- specific sample during the subsequent five years (the precise follow-up period was 4.5 years, this was chosen because of slight variations in the dates of the 1981, 1991 and 2001 Censuses which would have meant variable lengths of followup if end of the calendar year five years post census had been chosen as the end point). 
Data are drawn from the ONS LS, a record linkage study of approximately $1 \%$ of the population England and Wales. The sample was initially drawn from the 1971 Census and now includes information from subsequent censuses and from vital registration. The LS is a multi-cohort moving sample; members are lost through emigration and death and recruited through immigration and birth. The data set thus remains representative and may be used for cross sectional and cross sequential, as well as longitudinal, analyses. Strengths of the data include large sample size, low non-response and attrition bias (as census coverage is good and rates of linkage high); and inclusion of the institutional population. [27] Information from the census records of people in LS members' households is also available, although records for co-residents are not linked over time.

The sample for each decade comprised people aged 65 and over at the start of the decade who were still alive and in the sample ten years later. Those in the analysis sample for later decades thus include survivors from preceding decades together with those attaining the age of 65 in the interim and new recruits to the study. Initial modelling was undertaken separately for each decade but results reported here are for the pooled sample with decade as a co-variate. All analyses were undertaken for men and women separately, because of well established gender differences in living arrangements and mortality, and exclude very small proportions with missing information on relevant variables. People who at the start of each decade were resident in institutions were also excluded (as the intention was to analyse variations in moves to institutions) as were visitors (such as acute hospital inpatients) at the address of enumeration at start or end of decade.

\section{Measures}

Private (non-institutional) households in the census, and so in the LS, are defined as individuals or groups of co-residents who share a dwelling and have common housekeeping. People living in establishments where meals and services are communally provided (including those in schemes in which individual cooking facilities are available to fewer than half the residents) are identified as living in institutions. [27] For those in private households two classifications of household/family type were derived referring respectively to living arrangements at the start and end of each decade. These have been described in detail elsewhere [28] and use the census definition of a family which counts configurations of parents and never-married children (of any age) as part of the same family but not other combinations of relatives (such as widows living with married children). Start of decade living arrangements were grouped into four categories comprising: people living alone, ('Solitary'); people living with a spouse (or partner) only, ('Couple alone'); those in any other type of family, very largely comprising people living with a spouse and children or lone parents living with a never-married child, ('Family'); people living with relatives or friends not classified as being part of the same family or, less usually, in two family households ('Complex household').

The 'family' and 'complex household' groups were distinguished in the start-of-decade household classification because in the younger elderly population the former often includes people providing support to co-residents (e.g. 65 year old married men with 
children still at home), whereas the latter configuration is more likely to arise because of parental needs (e.g. 85 year old widows who have moved to live with a married daughter). However, the proportions in the 'family' category by the end of each decade (when sample members were aged 75 and over) were very small, so they were combined with the complex household group in the end of decade classification. Those living alone or just with a spouse at end of decade were also grouped together but are effectively distinguished in the analysis through inclusion of marital status as a co-variate. The third end of decade group comprised those living in an institution.

Other covariates were age in single years and housing tenure (distinguishing home owners from others) at start of the relevant decade and marital status at end of decade. Housing tenure was included as an indicator of socio-economic status and has been shown in previous studies to be associated with household changes, including moves to institutions. [28] There may also be a more direct relationship between housing wealth and entry to institutional care as means testing procedures mean that home owners (and their heirs) have particular disincentives to enter state funded residential care. [29] Marital status is an important indicator of availability of potential care from a spouse and also of likelihood of availability of a child (as in the cohorts considered few nevermarried people have children). End-of-decade indicators for marital status were chosen as being closer temporally to end-of-decade living arrangements and also to avoid problems with collinearity between initial household type and marital status. Finally, a dummy variable indicating decade of observation was derived.

\section{Results}

Table 1 shows the distribution of the three samples by variables used in the analysis. The ageing of the England and Wales population is reflected in larger sample sizes for the later decades and slight increases in mean age. The progressively lower proportion of never-married women in each of the three samples is a result of cohort differences in marriage; as would be expected, a much higher proportion of men than women were married. Changes in housing tenure patterns over time, including the consequences of the 1980 'right to buy' legislation which enabled public sector tenants to buy their homes at discounted prices, are evident in the large increase in the proportion of home owners. The distribution of the three samples by household type at the start and end of the relevant decade is shown in Table 2. The proportions living alone at the start of each decade were much higher for women than men and increased in successive decades, in the case of women from $34 \%$ in 1971 to $40 \%$ in 1991 . The proportions living alone or in a couple only household at the end of each decade also increased, for example from $76 \%$ for men in 1981 to $83 \%$ in 2001 . The proportions living with relatives declined and the proportions in institutions first rose and then fell.

Table 3 presents results from fitting multinomial regression models presented as relative risk ratios (and 95\% confidence intervals) for three end of decade contrasts: living in an institution rather than alone or with a spouse; living with relatives (family/complex) rather than alone or in a couple; and living in an institution rather than with relatives. Living in an institution, rather than alone or in a couple, was positively associated with 
older age, living in the family or complex household types at start of decade, being a tenant at start of decade and with being unmarried, particularly never-married, at end of decade. Living in a family/complex household at end of decade rather than alone or in a couple was positively - and very strongly- associated with being in one of these types of living arrangement at the start of the decade, with older age and with being unmarried (although this association was not as great as in the institution versus solitary/couple contrast), and negatively associated with being a tenant. The third contrast, between living in an institution versus with relatives, showed positive associations with older age, being a tenant and being unmarried and strong negative associations with initially living in a complex or family household and, to a lesser extent, with initially living with a spouse.

Relative to 1981-91, risk ratios of being in an institution at the end of the period, rather than in the alone/couple category group, were lower in 1991-2001 and in 1971-81 for both women and men. In 1991-2001 the risk of being in an institution rather than living with relatives was also significantly lower than in 1981-91 for women; among men this risk ratio was also lower in 1991-2001 than in 1981-91 but the difference was not statistically significant, possibly because of reduced statistical power in the smaller samples of men. For both men and women risks of being in an institution rather than living with relatives were nevertheless significantly higher for 1991-2001 than for 197181. Finally risks of being in a family/complex household rather than solitary/couple show a downward trend over time for women being significantly higher 1971-81 than 1981-91 but lower in 1991-2001. Among men the ratio for the last decade was lower than for 1981-91, but the difference was not statistically significant.

\section{Mortality by end of decade living arrangement}

Figure 1a and $\mathrm{b}$ show the survival of men and women for the four and a half years following each of the 1981, 1991 and 2001 Censuses by living arrangement at that point. In all periods those living alone or in a couple had the highest survival and those in institutions the lowest. However, whereas the survival of men and women living alone/in a couple or with relatives tended to improve over successive periods, the median survival of those in institutions in 2001 was about six months less than median survival of the 1991 institutional population

Results from fully adjusted Poisson regression models of mortality for the 4.5 years following each decade of interest are shown in Table 4. Information on co-variates comes from the same time points as shown in earlier tables so, for example, mortality 2001-05 is shown in relation to housing tenure in 1991; marital status in 2001, and household type in both 1991 and 2001.

Residence in an institution at end of decade was associated with elevated mortality risks in the subsequent 4.5 years; this excess mortality was greatest in the most recent period. Thus the IRR 2001-05 for residents in an institution in 2001 was 2.85 (95\% C.I. 2.683.03) for women and 2.80 (2.53-3.09) for men; comparable estimates for 1991-95 were 1.97 (1.86-2.09) for women and 2.19 (1.98-2.29) for men; the extent of excess mortality risk in 1981-85 was lower still. Women living with relatives had higher mortality than the reference category of those living alone or in a couple, but the excess risk was much less marked than for those in institutions and risk ratios were lower, for men and women, than 
for institutional residents. Household type at start of each relevant decade had no association with mortality 10-15 years later. Analysis of models including interaction terms (not shown) did, however, indicate raised mortality risks for men and women changing from living in a couple in1991 to an institution in 2001; (men: 1.31, 1.06-1.61 $\mathrm{p}<0.05$; women 1.1.6, 1.02-1.32 $\mathrm{p}<0.05$ ); and for women moving from living in the other family category to living in an a institution 1991-2001 $(1.43,1.09-1.88 \mathrm{p}<0.01)$ and men changing from living in a couple to living in an institution 1981-91 (1.31, 1.04-1.67 $\mathrm{p}<0.05)$.

Results also show higher mortality for widowed and divorced compared with married men in 1981-85 and for both widowed and divorced men and women in 2001-05 and a positive association between older age and mortality, which was greater in the 2000-05 period than earlier. There were no significant associations between being never-married and mortality once household type at two time points was controlled for, as shown in the table. In 2001-05 the mortality of men who had been tenants in 1991 was $25 \%$ higher than that of 1991 owner occupiers; among women this excess was $20 \%$. Mortality 1991-5 was also raised for men who had been tenants in 1981.

\section{Discussion}

For men and women risks of moving to an institution 1991-2001 relative to chances of living alone or in a couple were lower than in 1981-1991. For women risks of moving to an institution rather than living with relatives were also significantly lower 1991-2001 than in 1981-91, although for both men and women they were higher than in 1971-81. Chances of living with relatives rather than alone or with a spouse were lower in 19912001 than 1971-81 or, for women, in 1981-91. Excess mortality of the institutional population was greatest in 2001-05. Among women, those living with relatives also had raised mortality risks, but these were considerably less than the risks for those in institutions suggesting that these populations are not equivalent in terms of health status. Housing tenure was more strongly associated with mortality risk in 2001-05 than in earlier periods probably because tenants by then comprised a smaller and relatively more disadvantaged group. It is not clear why age was more strongly associated with mortality in 2001-05 than in previous periods but investigation using data from the whole England and Wales population showed a similar increase in the strength of the association between age and mortality, a change which merits further analysis.

These results are based on a large nationally representative data set that is minimally affected by non response and attrition and allows comparisons over three decades. However the long intervals between census data capture points makes it impossible to pinpoint dates of household transitions; we do not know, for example, whether changes in household type between 1991 and 2001 pre or post dated implementation of the NHS Community Care Act, although given the high mortality of residents in institutions it is unlikely that many of those in institutional care in 2001 had been there for more than seven years. The lack of detailed information on health, family support from outside the household or use of services presents a further limitation, particularly in this design as the analysis was restricted to variables included in all the censuses of interest. Studies including more detailed information have been able to identify factors predictive of entry to institutions more precisely and in particular have identified the importance of 
conditions such as dementia and the preventive role of extra-household support from relatives and formal services. [30-33] However, in many cases these more detailed findings have been restricted to local populations and do not allow consideration of changes over time $[30,31]$ and as yet we lack data sets which combine detail with size and availability of data for different time periods.

The findings suggest that policy changes influence the residential choices of older people and that more specifically, the NHS and Community Care Act and other reforms in the 1990s led to a reduction in institutional admission and that those who were admitted had a poorer health status overall than people entering institutional care in previous decades. Among women the balance between institutional and co-resident family care also shifted slightly towards the latter in the 1991-2001 decade (although not back to the 1971-81 level), but also towards living alone (or with a spouse). The targeting of community services on those deemed most at risk of institutional admission, which included increases in hours of help provided for this group, [26] may have enabled more people to remain in the community for longer, even if living alone or just with a spouse. Overall chances of living with relatives were lower in 1991-2001 than in previous decades suggesting other influences driving a continued trend towards increased residential independence among older people. International comparisons would improve our ability to identify these differing drivers, and perhaps identify more clearly the effects of policy. Finally, despite the high mortality of residents in institutions, it is noteworthy that $36 \%$ of women and $26 \%$ of men in institutional care in 2001 were still alive three years later, a finding relevant to both families and service providers planning financing of care. 


\section{References}

1 Grundy E. The living arrangements of elderly people. Rev Clin Gerontol 1992; 2: 353361.

2 Pampel F C. Trends in living alone among the elderly in Europe. In: Rogers A, ed.

Elderly Migration and Population Redistribution. London: Belhaven Press 1992:97-117.

3 Tomassini C, Glaser K, Wolf D, Broese van Grenou M, Grundy E. Living

arrangements among older people: an overview of trends in Europe and the USA. Popul

Trends 2004; 115: 24-34.

4 McGarry K, Schoeni RF. Social security, economic growth, and the rise in elderly widows' independence in the twentieth century. Demography 2000; 37: 221-36.

5. Hoenig H, Taylor DH, Sloan FA. Does assistive technology substitute for personal assistance among the disabled elderly? Am J Public Health 2003; 93:330-7.

6 Freedman VA, Agree EM, Martin LG, Cornman LC. Trends in the use of assistive technology and personal care for late-life disability, 1992-2001. Gerontologist 2006: 46:124-7.

7 Goldscheider FK, Waite LS. New families, no families? Berkeley, CA: University of California Press 1991.

8 Wolf DA. Population change: friend or foe of the chronic care system? Health Aff 2001; 20: 28-42. 
9 Murphy M, Grundy E. Mothers with living children and children with living mothers: the role of fertility and mortality in the period 1911-2050. Popul Trends 2003; 112: 3645.

10 Murphy M, Martikainen P, Pennec S. Demographic change and the supply of potential family supporters in Britain, Finland and France in the period 1911-2050. Eur J Popul 2006; 22:219-40.

11 Tomassini C, Grundy E, Kalogirou S. Potential family support for older people 20002030. In: Gaymu J, Festy P, Poulain M, Beets G eds., Future elderly living conditions in Europe, Paris: Institut National d'Etudes Demographiques 2008: 71-96.

12 Doty P, Jackson M E, Crown W. The impact of female caregivers' employment status on patterns of formal and informal eldercare. Gerontologist 1998; 38:331-341.

13 Johnson RW, Lo Sasso AT. Family support of the elderly and female labour supply: trade-offs among caregiving, financial transfers and work: evidence from the US Health and Retirement Survey. In Harper S. ed. Families in ageing societies, Oxford: Oxford University Press 2004:114-142.

14 Daatland SO, Lowenstein A. Intergenerational solidarity and the family-welfare state balance. Eur J Ageing; 2:171-

15 Soldo B, Freedman V. Care of the elderly: division of labour among the family, market and state. In Martin LG, Preston SH eds. Demography of Aging. Washington DC: National Academy Press 1994:195-216.

16 Ogawa N, Retherford RD. Shifting the cost of caring for the elderly back to families in Japan: Will it work? Popul Dev Rev 1997; 23: 59-96. 
17 Johansson L, Sundström G, Hassing LB. State provision down offspring's up: the reverse substitution of old age care in Sweden. Ageing Soc 2003; 23: 269-280.

18 Means R, Smith R. From Poor Law to Community Care: The development of services for elderly people. Bristol: Policy Press 1998.

19 Wanless D. Securing good care for older people: taking a long-term view. London: King's Fund, 2006.

20 Grundy E, Arie T. Falling rate of provision of residential care for the elderly. BMJ $1982 ; 284 ; 791-802$

21 Grundy E. Community care for the elderly 1976-1984. BMJ 1987; 294: 626-629

22 Brocklehurst JC. Long-term care- United Kingdom. In Tallis RC, Fillit HM, Brocklehurst JC eds Brocklehurst's Textbook of Geriatric Medicine and Gerontology $\left(5^{\text {th }}\right.$ Edition). Edinburgh: Churchill Livingstone 1998: 1551-8.

23 Laing W, Buisson Ltd. Care of the elderly - UK Market Report 2005. London, Laing and Buisson 2005.

24 Laing W. Financing long-term care: the crucial debate. London: Age Concern England 1996.

25 Grundy E, Glaser K. Trends in, and transitions to, institutional residence among older people in England and Wales, 1971 to 1991. J Epidemiol Community Health 1997; 51:531-540.

26 Pickard L. The decline of intensive intergenerational care of older people in Great Britain, 1985-1995. Popul Trends 2003; 110: 31-41

27 Blackwell L, Lynch K, Smith J, Goldblatt P. Longitudinal Study 1971-2001: completeness of census linkage. London: Office for National Statistics 2003. 
28 Grundy E, Jitlal M. Socio-demographic variations in moves to institutional care 19912001: a record linkage study from England and Wales. Age Ageing 2007; 36: 1-7

29 Hancock R, Arthur A, Jagger C, Matthews R. The effect of older people's economic resources on care home entry under the United Kingdom's long-term care financing system. J Gerontol B Psychol Sci Soc Sci 2002; 57:S285-93

30 Boaz RF, Muller CF. Predicting the risk of permanent nursing-home residence- the role of community help as indicated by family helpers and prior living arrangements. Health Serv Res 1994; 29:391-414.

31 Crawford VLS, Beringer TRO, Stout RW. Comparison of residential and nursing home care before and after the 1991 community care policy. BMJ 1999; 318:366.

32 Challis D, Mozley CG, Sutcliffe C, Bagley H, Price L, Burns A, Huxley P, Cordingly L. Dependency in older people admitted to care homes. Age Ageing 2000; 29:255-60.

33 Aguero-Torres H, von Strauss E, Viitanen M, Winblad B, Fratiglioni L. Insitutionalization in the elderly: The role of chronic diseases and dementia. Crosssectional and longitudinal data from a population-based study. J Clin Epidemiol 2001;

54: 795-801. 
Table 1. Distribution of 1971-81, 1981-91 and 1991-2001 samples by sociodemographic characteristics.

\begin{tabular}{|c|c|c|c|c|c|c|}
\hline & \multicolumn{2}{|c|}{$1971-81$} & \multicolumn{2}{|c|}{ 1981-91 } & \multicolumn{2}{|c|}{$1991-2001$} \\
\hline & Men & Women & Men & Women & Men & Women \\
\hline \multirow[t]{2}{*}{ Mean age $^{1}(\mathrm{SD})$} & 69.5 & 70.6 & 70.0 & 71.2 & 70.0 & 71.2 \\
\hline & $(4.1)$ & $(4.7)$ & $(4.3)$ & $(5.0)$ & $(4.4)$ & $(5.0)$ \\
\hline Owner occupier ${ }^{1}(\%)$ & 58.4 & 52.7 & 61.3 & 56.0 & 72.6 & 65.8 \\
\hline Tenant $^{1}(\%)$ & 41.6 & 47.7 & 38.7 & 44.0 & 27.4 & 34.2 \\
\hline $\operatorname{Married}^{2}(\%)$ & 61.2 & 20.2 & 63.8 & 23.8 & 63.6 & 25.9 \\
\hline Never-married $^{2}(\%)$ & 6.1 & 13.0 & 5.4 & 10.1 & 5.5 & 7.0 \\
\hline Wid./div/ $/^{2}(\%)$ & 32.7 & 66.8 & 30.8 & 66.2 & 30.9 & 67.1 \\
\hline $\mathrm{N}$ & 8,482 & 17,259 & 10,971 & 20,978 & 13,587 & 23,107 \\
\hline
\end{tabular}

${ }^{1}$ At start of decade; ${ }^{2}$ at end of decade.

Source: Analysis of ONS Longitudinal Study data. 
Table 2. Distribution by household type at start and end of decade, men and women aged 65 and over at start of decade, 1971-81; 1981-91 and 1991-2001.

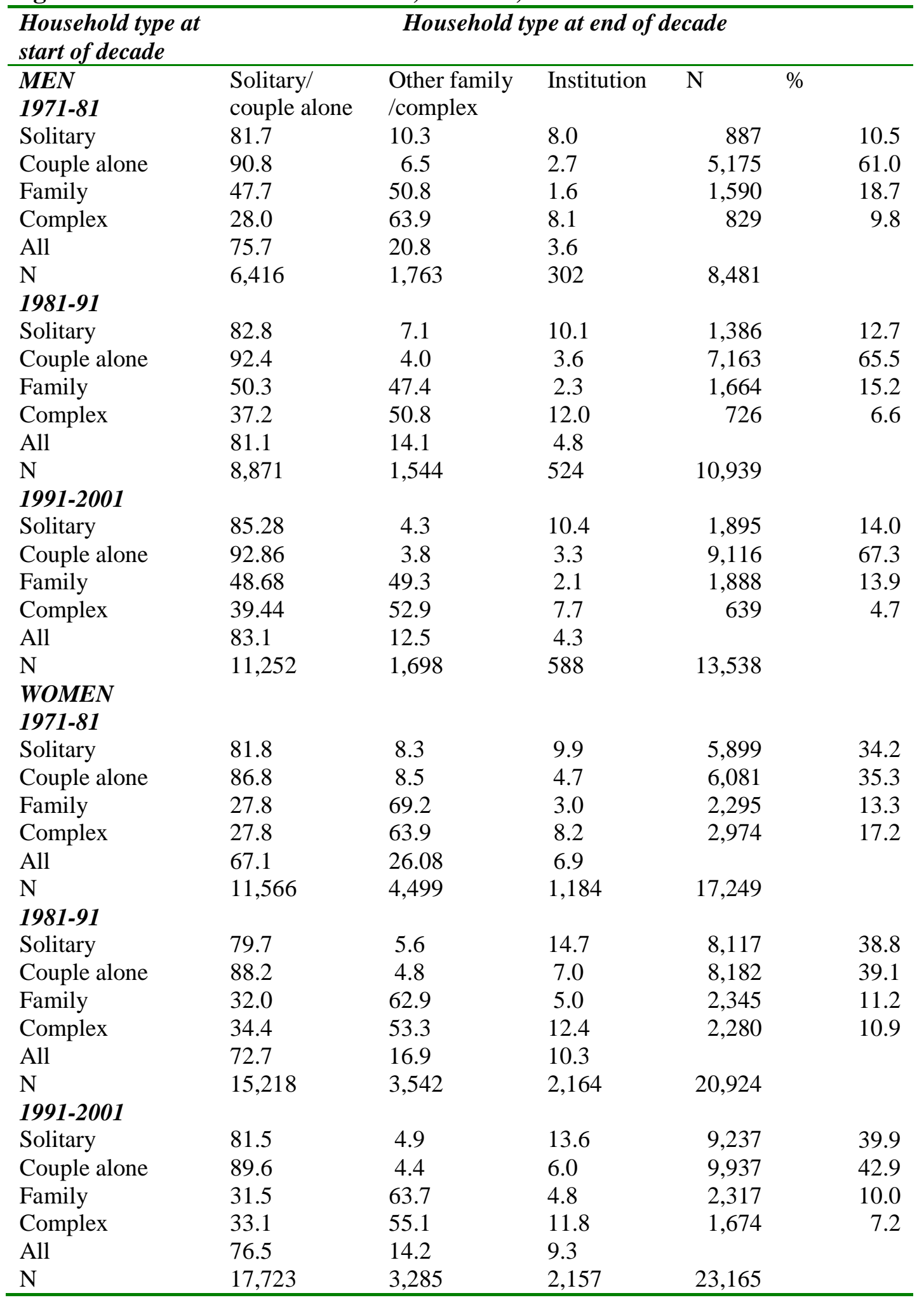

Source: Analysis of ONS Longitudinal Study data. 
Table 3. Results from multinomial regression models of transitions between household types 1971-81; 1981-91 and 1991-2001, men and women aged 65 and over at start of decade.

\begin{tabular}{|c|c|c|c|c|c|c|}
\hline \multirow[b]{3}{*}{ MEN } & \multicolumn{6}{|c|}{ Household type at end of decade } \\
\hline & \multicolumn{2}{|c|}{$\begin{array}{l}\text { Institution vs. } \\
\text { solitary/couple alone }\end{array}$} & \multicolumn{2}{|c|}{$\begin{array}{l}\text { Family/complex vs. } \\
\text { solitary/couple alone }\end{array}$} & \multicolumn{2}{|c|}{$\begin{array}{l}\text { Institution vs. } \\
\text { Family/complex }\end{array}$} \\
\hline & RRR & 95\% C.I & RRR & 95\% C.I & RRR & $95 \%$ C.I \\
\hline Age & $1.16^{* * *}$ & $1.15-1.17$ & $1.05 * * *$ & $1.04-1.06$ & $1.10^{* * *}$ & $1.09-1.12$ \\
\hline \multicolumn{7}{|l|}{ Household type ${ }^{1}$} \\
\hline Solitary (Ref.) & 1.00 & & 1.00 & & 1.00 & \\
\hline Couple alone & 0.94 & $0.81-1.10$ & $1.18^{*}$ & $1.02-1.37$ & $0.80^{*}$ & $0.66-0.98$ \\
\hline Family & $1.47 * * *$ & $1.15-1.87$ & $27.02 * * *$ & $23.20-31.46$ & $0.05^{* * *}$ & $0.04-0.07$ \\
\hline Complex & $3.72^{* * * *}$ & $3.04-4.55$ & $26.24 * * *$ & $22.37-30.77$ & $0.14 * * *$ & $0.11-0.18$ \\
\hline \multicolumn{7}{|l|}{ Housing tenure ${ }^{1}$} \\
\hline Owner occupier & 1.00 & & 1.00 & & 1.00 & \\
\hline Tenant & $1.44 * * *$ & $1.27-1.60$ & $0.88 * *$ & $0.81-0.95$ & $1.63 * * *$ & $1.43-1.85$ \\
\hline \multicolumn{7}{|l|}{ Marital status $^{2}$} \\
\hline Married (Ref.) & 1.00 & & 1.00 & & 1.00 & \\
\hline Never-married & $5.86^{* * *}$ & 4.64-7.41 & $2.32^{* * * *}$ & $1.96-2.74$ & $2.53^{* * *}$ & $1.95-3.27$ \\
\hline Wid./divorced & $4.75^{* * *}$ & 4.11-5.49 & $2.74 * * *$ & 2.51-2.99 & $1.73 * * *$ & $1.48-2.04$ \\
\hline \multicolumn{7}{|l|}{ Period } \\
\hline 1971-81 & $0.71 * *$ & $0.68-0.92$ & $1.38^{* * * *}$ & $1.26-1.52$ & $0.57 * * *$ & $0.49-0.68$ \\
\hline 1981-91 (Ref). & 1.00 & & 1.00 & & 1.00 & \\
\hline 1991-2001 & $0.84 * *$ & $0.74-0.96$ & 0.94 & $0.86-1.03$ & 0.90 & $0.78-1.04$ \\
\hline $\mathrm{N}$ & 32,915 & & 32,915 & & 32,915 & \\
\hline \multicolumn{7}{|l|}{ WOMEN } \\
\hline Age & $1.18^{* * * *}$ & $1.17-1.19$ & $1.06 * * *$ & $1.05-1.07$ & $1.12 * * *$ & $1.11-1.12$ \\
\hline \multicolumn{7}{|l|}{ Household type ${ }^{1}$} \\
\hline Solitary (Ref.) & 1.00 & & 1.00 & & 1.00 & \\
\hline Couple alone & 1.07 & $0.99-1.15$ & $1.34 * * *$ & $1.24-1.46$ & $0.79 * * *$ & $0.71-0.88$ \\
\hline Family & $1.96^{* * * *}$ & $1.71-2.25$ & $42.30 * * *$ & $38.94-45.94$ & $0.05^{* * *}$ & $0.04-0.05$ \\
\hline Complex & $2.49 * * *$ & $2.25-2.75$ & $25.88 * * *$ & $23.91-28.01$ & $0.10^{* * *}$ & $0.09-0.11$ \\
\hline \multicolumn{7}{|l|}{ Housing tenure ${ }^{1}$} \\
\hline Owner occupier (Ref.) & 1.00 & & 1.00 & & 1.00 & \\
\hline Tenant & $1.20^{* * *}$ & $1.13-1.27$ & $0.85^{* * *}$ & $0.80-0.89$ & $1.41^{* * *}$ & $1.31-1.52$ \\
\hline \multicolumn{7}{|l|}{ Marital status $^{2}$} \\
\hline Married (Ref.) & 1.00 & & 1.00 & & 1.00 & \\
\hline Never-married & $4.58^{* * *}$ & $3.94-5.32$ & $2.28 * * *$ & $2.01-2.53$ & $2.03 * * *$ & $1.71-2.42$ \\
\hline Wid./divorced & $3.29 * * *$ & $2.91-3.71$ & $2.59 * * *$ & $2.39-2.80$ & $1.27 * * *$ & $1.11-1.46$ \\
\hline \multicolumn{7}{|l|}{ Period } \\
\hline $1971-81$ & $0.75^{* * *}$ & $0.70-0.82$ & $1.48^{* * *}$ & $1.39-1.58$ & $0.51^{* * *}$ & $0.47-0.56$ \\
\hline 1981-91 (Ref). & 1.00 & & 1.00 & & 1.00 & \\
\hline 1991-2001 & $0.78^{* * *}$ & $0.73-0.84$ & $0.90 * *$ & $0.84-0.96$ & $0.87 * *$ & $0.80-0.95$ \\
\hline $\mathrm{N}$ & 61,237 & & & & & \\
\hline
\end{tabular}

${ }^{1}$ At start of decade; ${ }^{2}$ at end of decade.

Source: Analysis of ONS Longitudinal Study data. ${ }^{*} \mathrm{p}<0.05 ; * * \mathrm{p}<0.01$; $* * * \mathrm{p}<0.001$ 
Table 4. Results from Poisson regression analysis of mortality by household type at start and end of relevant decade, 1981-85; 1991-95 and 2001-05, men and women aged $\mathbf{6 5}$ and over at start of decade.

\begin{tabular}{|c|c|c|c|c|c|c|}
\hline & 1981-85 & & 1991-95 & & 2001-05 & \\
\hline$M E N$ & IRR & 95\% C.I. & IRR & 95\% C.I. & IRR & $95 \%$ C.I. \\
\hline Age & $1.04 * * *$ & $1.04-1.05$ & $1.03 * * *$ & $1.03-1.04$ & $1.08 * * *$ & $1.08-1.09$ \\
\hline Owner occupier (Ref.) & 1.00 & & 1.00 & & 1.00 & \\
\hline Tenant & 1.04 & $0.99-1.10$ & $1.08 * *$ & $1.03-1.14$ & $1.25 * * *$ & $1.18-1.33$ \\
\hline \multicolumn{7}{|c|}{ Household type at start of decade } \\
\hline Solitary (Ref.) & 1.00 & & 1.00 & & 1.00 & \\
\hline Couple alone & 1.04 & $0.94-1.15$ & 1.02 & $0.93-1.11$ & 0.98 & $0.90-1.08$ \\
\hline Family & 1.04 & $0.92-1.17$ & 0.97 & $0.87-1.09$ & 1.00 & $0.88-1.13$ \\
\hline Complex & 1.02 & $0.90-1.16$ & 0.98 & $0.86-1.10$ & 0.94 & $0.81-1.09$ \\
\hline \multicolumn{7}{|c|}{ Household type at end of decade } \\
\hline Solitary/couple (Ref.) & 1.00 & & 1.00 & & 1.00 & \\
\hline Family/complex & 1.08 & $0.99-1.17$ & 1.07 & $0.98-1.16$ & 1.10 & $1.00-1.21$ \\
\hline Institution & $1.91 * * *$ & $1.68-2.18$ & $2.19 * * *$ & $1.98-2.29$ & $2.80 * * *$ & $2.53-3.09$ \\
\hline \multicolumn{7}{|l|}{ Marital status } \\
\hline Married (Ref.) & 1.00 & & 1.00 & & 1.00 & \\
\hline Single & 1.04 & 0.91-1.19 & 1.00 & $0.88-1.15$ & 1.11 & $0.96-1.28$ \\
\hline Widowed/divorced & $1.10 * *$ & $1.03-1.18$ & 1.02 & $0.96-1.08$ & $1.11 *$ & $1.03-1.18$ \\
\hline Number of deaths & 1162 & & 1230 & & 1204 & \\
\hline \multicolumn{7}{|l|}{ WOMEN } \\
\hline Age & $1.04 * * *$ & $1.04-1.04$ & $1.04 * * *$ & $1.04-1.04$ & $1.09 * * *$ & $1.09-1.09$ \\
\hline Owner occupier (Ref.) & 1.00 & & 1.00 & & 1.00 & \\
\hline Tenant & 1.04 & $1.00-1.08$ & 1.04 & $1.00-1.08$ & $1.20 * * *$ & $1.15-1.26$ \\
\hline \multicolumn{7}{|c|}{ Household type at start of decade } \\
\hline Solitary (Ref.) & 1.00 & & 1.00 & & 1.00 & \\
\hline Couple alone & 0.99 & $0.93-1.04$ & 0.97 & $0.93-1.02$ & 1.03 & $0.97-1.10$ \\
\hline Family & 0.93 & $0.87-1.01$ & 0.96 & $0.89-1.04$ & 0.99 & $0.90-1.08$ \\
\hline Complex & 0.98 & $0.91-1.05$ & 1.01 & 0.95-1.09 & 1.03 & $0.94-1.13$ \\
\hline \multicolumn{7}{|c|}{ Household type at end of decade } \\
\hline Solitary/couple (Ref.) & 1.00 & & 1.00 & & 1.00 & \\
\hline Family/complex & $1.15 * * *$ & $1.08-1.22$ & $1.10 * *$ & $1.04-1.17$ & $1.25 * * *$ & $1.15-1.35$ \\
\hline Institution & $1.85 * * *$ & $1.72-1.99$ & $1.97 * * *$ & $1.86-2.09$ & $2.85 * * *$ & $2.68-3.03$ \\
\hline \multicolumn{7}{|l|}{ Marital status } \\
\hline Married (Ref.) & 1.00 & & 1.00 & & 1.00 & \\
\hline Single & 0.98 & $0.90-1.07$ & 0.97 & $0.89-1.05$ & 1.04 & $0.93-1.16$ \\
\hline Widowed/divorced & 0.99 & $0.93-1.05$ & 1.02 & $0.97-1.08$ & $1.08 *$ & $1.00-1.15$ \\
\hline Number of deaths & 1596 & & 1705 & & 1641 & \\
\hline
\end{tabular}

Source: Analysis of ONS Longitudinal Study data.

$* \mathrm{p}<0.05 ; * * \mathrm{p}<0.01 ; * * * \mathrm{p}<0.001$ 
Figure 1. Survival (proportion surviving) by living arrangement at census, 1981-5, 19915 and 2001-05. 


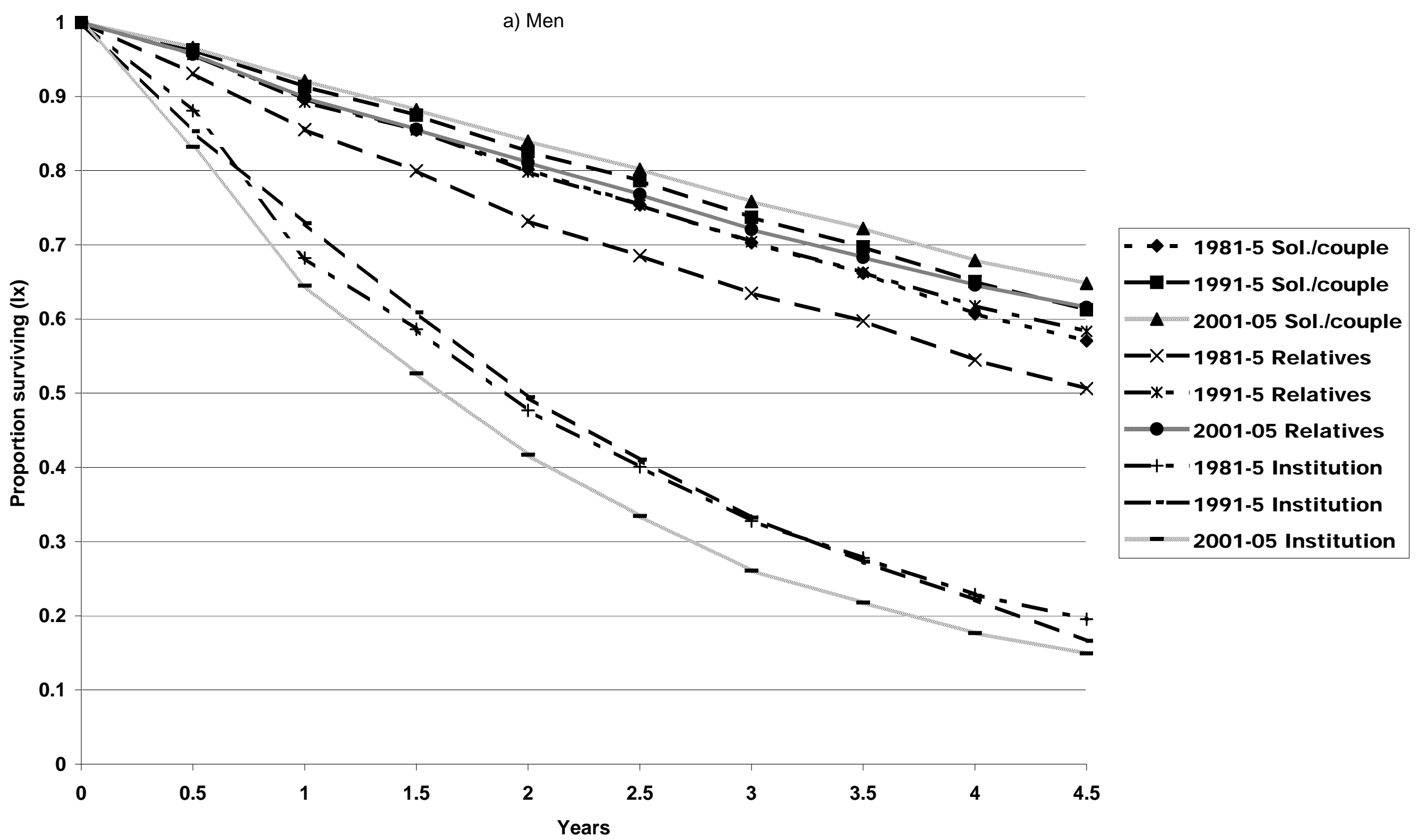




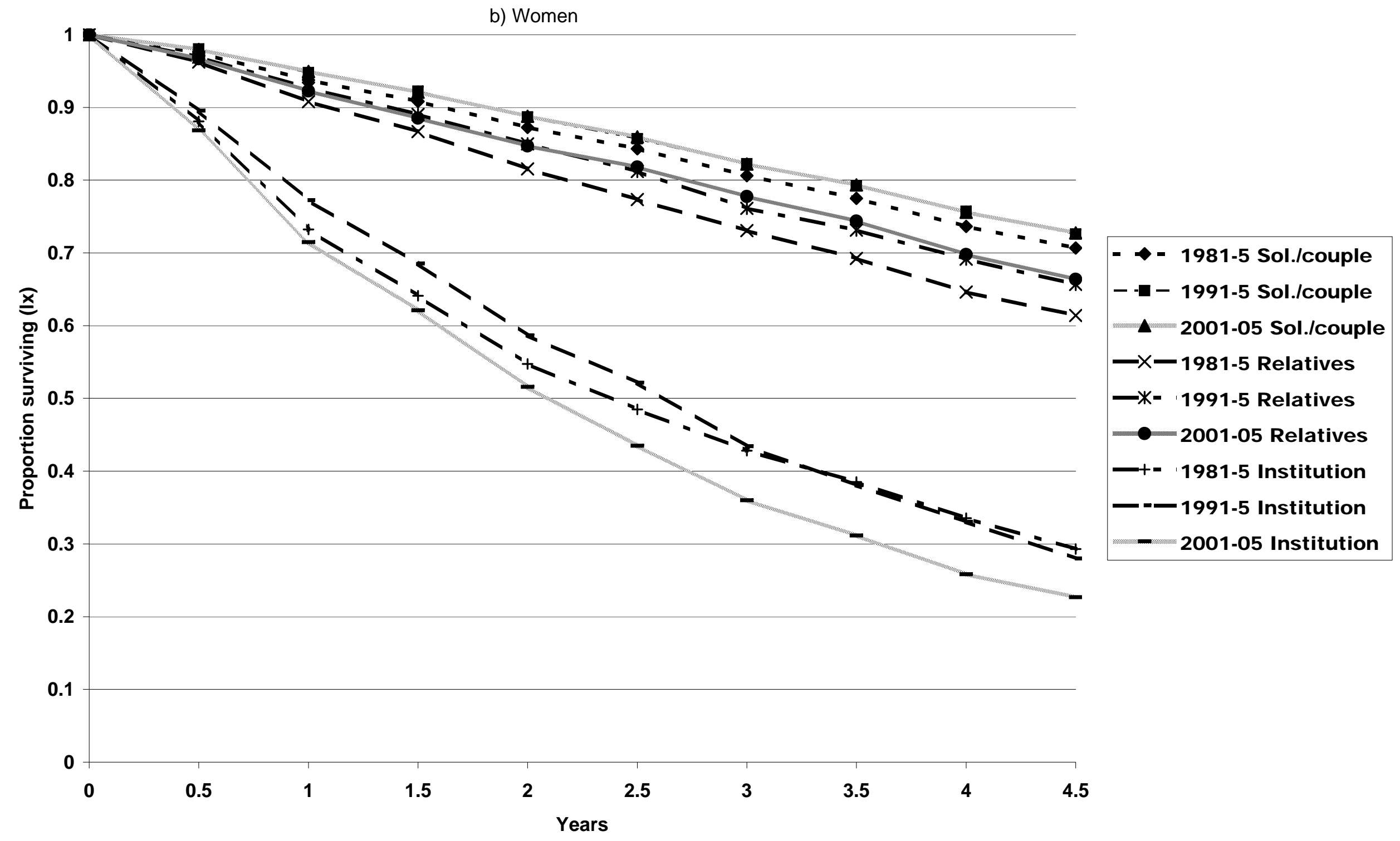

